\title{
RUBENS, Pedro. 0 rosto plural da fé: da ambiguidade religiosa ao discernimento do crer. São Paulo: Loyola, 2008. 199 p.
}

Fabiano Victor Campos *

A fé cristã, em suas novas, múltiplas e ambíguas formas de manifestação, tem despertado a atenção de pesquisadores dos mais diversos campos do saber. Testemunho desse interesse é o recente estudo de Pedro Rubens, apresentado como tese doutoral em Teologia no Centre Sèvres (Centro Universitário) dos jesuítas em Paris e que, por razões didáticas e de facilitação de acesso, chega às mãos dos leitores da língua portuguesa dividido em três tomos.

O título da obra em francês, Discerner la foi dans des contextes religieux ambigus (Discernir a fé nos contextos religiosos ambíguos), expressa as duas perspectivas hermenêuticas adotadas: uma primeira, de cunho sócio-histórico, que permeia praticamente a totalidade do presente volume por nós apresentado e que, na esteira da metodologia adotada pelos teólogos latino-americanos da Teologia da Libertação, busca contextualizar a experiência de fé; a outra, de caráter propriamente teológico, que visa refletir sobre o significado do ato de fé cristão, empreitada essa apenas iniciada no capítulo conclusivo do volume aqui analisado. O que significa crer em meio a contextos religiosos ambíguos? Tal é a pergunta levantada e discutida nesse estudo, e que se apresenta como o seu fio condutor.

Atentemo-nos à consideração do primeiro volume. Nele Rubens propõe-se a refletir sobre o significado do ato de fé cristão (hermenêutica teológica) a partir da análise do hodierno cenário religioso brasileiro, marcado sobretudo por três novas expressões da fé cristã: as Comunidades Eclesiais de Base (CEBs), a Renovação Carismática Católica (RCC) e o Pentecostalismo, de caráter protestante, mas que revela traços de sincretismo. Parte-se da hipótese de que essas três expressões religiosas podem ser consideradas novas

\footnotetext{
* É graduado em Filosofia pela PUC Minas. Possui especialização em Temas Filosóficos pela UFMG. Mestre em Ciências da Religião pela UFJF. É professor de Metafísica no Seminário Provincial Sagrado Coração de Jesus, em Diamantina - MG, e de Filosofia nos colégios Santo Agostinho e Arnaldo, em Belo Horizonte MG. País de origem: Brasil. E-mail: fvocampos@ hotmail.com
} 
configurações da fé cristã em território nacional ou, na terminologia adotada por Rubens, "novas figuras de ser Igreja". Isto pelo fato de apresentarem traços das dimensões essenciais da fé cristã, a saber: as três figuras se autodefinem como experiência do Espírito Santo e se dizem, para usar uma expressão comum ao universo do cristianismo, portadoras de uma "Boa Nova" para a vivência cristã; além disso, elas exprimem uma busca incansável do sentido real da fé cristã para a vida concreta das pessoas.

A escolha dessas expressões da fé cristã como objeto de análise justifica-se, segundo o próprio autor, por serem essas figuras "as mais representativas e problemáticas" do contexto religioso brasileiro no período pós- conciliar. Rubens submete essas figuras religiosas a uma leitura sócio-histórica e teológica, porém evita a compreensão de uma figura religiosa unicamente em função do declínio de outra. Situa-as em uma mesma matriz religiosa, o catolicismo popular, entendido como matriz da fé cristã no Brasil. Nelas encontra traços tanto de filiação quanto de diferenciação em relação àquele.

Em sua análise do catolicismo popular, Rubens parte de algumas premissas: a da predominância do catolicismo no Brasil, cuja expressão popular representa a "memória viva" da evangelização do país no decorrer de sua história; a de que o catolicismo brasileiro possui múltiplas faces, e sua expressão popular é a forma mais representativa de sua real complexidade; enfim, interpreta a atual situação de efervescência religiosa como uma reconfiguração do cristianismo, de modo que tal situação encontra-se imbricada com a história, a gênese e a formação sociorreligiosa do povo brasileiro.

Enfrenta a ambiguidade do termo "catolicismo popular", ora considerado como uma forma específica da religiosidade popular ora concebido como uma forma específica do catolicismo. Constata que o catolicismo popular se inscreve no universo da religiosidade popular, ao mesmo tempo que lhe confere forma e expressão, ou seja, a religiosidade popular "subsiste" no catolicismo popular.

Seja para captar os elementos fundantes dessa matriz religiosa brasileira seja para desenvolver critérios de interpretação, faz-se mister traçar-lhe um panorama históricosocial. Tal é a empreitada assumida por Rubens nesse primeiro capítulo, no qual tece uma leitura genealógica do catolicismo popular, percorrendo três caminhos distintos.

Em um primeiro momento, retoma a discussão acerca da identidade católica atribuída ao Brasil pelos dados estatísticos e questionada por alguns estudiosos desde o 
alvorecer do século XX. Nas análises que contestam tal identidade, afirmando se tratar de pura "ilusão catequética" ou identificando no catolicismo brasileiro uma espécie de "religião popular sincrética travestida de contornos católicos", Rubens entrevê um desnível entre o catolicismo popular brasileiro e o ideal de catolicismo oficial universal. A questão da afirmação do Brasil como o maior país católico do mundo é deixada em aberto.

Num segundo momento, a abordagem do autor movimenta-se da historiografia do catolicismo brasileiro à sua genealogia. Tal passagem é realizada por meio da análise das estruturas religiosas europeias, africanas e ameríndias que, segundo Comblin, engendraram e estruturaram o catolicismo popular brasileiro. Todavia, a constatação da predominância da estrutura europeia em detrimento das outras, conduz o autor a levar em consideração outros tipos de estruturas: antropológicas, simbólicas, culturais etc.

Enfim, o autor caminha das tipologias ideais à pluralidade concreta do catolicismo popular no Brasil.

No segundo capítulo, Rubens traça um panorama da gênese e da evolução das CEBs em três fases, correspondentes a três décadas. Após situar os primeiros embriões de CEBs entre 1964 e 1968, Rubens identifica a fase de florescimento das CEBs em torno dos anos 70. Esse primeiro período é marcado pela irrupção dos pobres como "fato histórico". Segue, portanto, os passos da Conferência de Medellín na linha da identificação com os mais pobres. Rubens identifica e apresenta as seguintes características das CEBs nesse período: articulação entre fé e vida; espírito criativo na interpretação das Sagradas Escrituras e na liturgia; influência na vida pública; encontros intereclesiais.

Situado em torno da década de 80 , o segundo período inaugura-se pela conferência episcopal latino-americana de Puebla (1979) e consolida a opção preferencial pelos pobres, considerando-os os preferidos de Deus.

O terceiro período organiza-se em torno dos anos 90. Neste, sublinha-se a preocupação com as religiões e culturas no espírito de Santo Domingo.

Após o recorte diacrônico, o autor se propõe a discutir o problema da definição das CEBs. Caminhando na esteira das análises empreendidas por Pedro Ribeiro de Oliveira e de Clodovis Boff, Rubens distingue quatro elementos formais característicos de uma CEB: um encontro semanal da comunidade, mesmo sem a possibilidade de celebração da eucaristia; uma equipe animadora ou um conselho para a reflexão e a organização da vida da 
comunidade e, também, para assegurar os laços de comunhão com as atividades paroquiais e diocesanas; a centralidade da Palavra de Deus na vida da comunidade, expressa pela existência e atuação dos círculos bíblicos; a participação de membros das CEBs em alguma organização popular, social e/ou política.

Por outro lado, um conceito "material", de natureza propriamente teológica, é deduzido dos três termos que dão nome a esse "novo jeito de ser Igreja": comunidade, eclesial, base. Como características que definem a eclesialidade das CEBs, Pedro Rubens aponta a Bíblia, a participação e a luta. Já o termo "base" designa o que é elementar, isto é, as CEBs como células elementares da Igreja.

Tal como na análise das CEBs, Rubens estuda, em um terceiro capítulo, a gênese e o crescimento da RCC em três períodos. O tempo de gestação e de surgimento é situado entre 1966 e o final dos anos 70. Já o período de crescimento e de estruturação vai de 1972 ao final da década de 80 . As categorias weberianas de carisma e instituição são utilizadas para caracterizar a metamorfose da RCC rumo à sua "oficialização". Por fim, em resposta à investida neopentecostal autônoma, a RCC adentra o tempo da ofensiva na mídia (era do "televangelismo") e do marketing religioso, período no qual se inscreve a geração de padres artistas ou cantores e que se estende de 1983 aos anos 90. Neste período, a RCC toma a forma de um "movimento de massa".

Ressalta-se a aprovação eclesiástica oficial em relação ao movimento desde os seus primórdios, que lhe confere um estatuto de legitimidade, porém não sem mencionar algumas atitudes de reserva e hesitação. Evita-se explicar o sucesso da RCC por meio do suposto fracasso do discurso socializante da Igreja, empreendido principalmente pela Teologia da Libertação, ou pelo diagnóstico do declínio das CEBs ou, ainda, por uma estratégia institucional da Igreja Católica para recuperar fieis desgarrados. Não obstante, o autor realiza um julgamento do fenômeno religioso em foco, destacando a "ambivalência da experiência". Por um lado, enumera alguns frutos suscitados pelo movimento, enfeixando-os em duas experiências fundamentais: experiência espiritual pessoal e de pertença comunitária. Por outro lado, apresenta o que denomina de "situações-limites", mas que aos nossos olhos parece corresponder a uma análise permeada de critérios teológicos implícitos: o fato de a RCC não dar a devida importância ao engajamento-social dos cristãos; de tender ao "paralelismo pastoral", de modo a operar sem vínculo com a 
organização diocesana e paroquial, isto é, sem laços com a Igreja local; de ligar-se a uma teologia da imediatez; de tender-se à busca do" maravilhoso", resvalando-se no “emocionalismo". Além desses "pontos críticos intimamente ligados", o autor também aponta "promessas", não cumpridas pelo movimento, de renovação de toda a Igreja e de ecumenismo.

No quarto capítulo, o estudo histórico do pentecostalismo é realizado em três tempos. Constata-se sua chegada e sua constituição no período de 1910 aos anos 50, período do assim chamado "pentecostalismo clássico"; sua expansão e consolidação são assinaladas durante os anos 60 e 70; e, por fim, sua explosão como movimento de massas é situada entre o fim dos anos 70 até os dias hodiernos. Este último período, que Rubens, nos passos de R. Mariano, propõe chamar de neopentecostalismo, é caracterizado sobretudo pelo "televangelismo", em profunda mudança de uma visão espiritualista para uma materialista. Seguindo a mesma linha metodológica, após a sumária apresentação histórica, Rubens detém-se nos eixos estruturais da experiência pentecostal, tais como a ênfase no pecado e no mal, no seio de uma visão dualista do mundo e do ser humano; o apelo à autoridade da Bíblia, citada de modo direto, arbitrário e, com frequência, fundamentalista; o "batismo no Espírito" como experiência fundadora; o estilo emocional, presente nas diferentes formas do movimento pentecostal; a clássica tensão entre carisma e instituição, geradora de uma dispersão espacial, temporal; a insurreição emocional dos pobres num ambíguo processo de submissão dos mesmos, mas também de restituir-lhes a dignidade perdida ou nunca obtida.

Após as análises sócio-históricas engendradas nos capítulos anteriores, o autor propõe, em capítulo conclusivo, uma abordagem crítica das questões propriamente teológicas que essas três novas expressões da fé cristã suscitam. Todavia, convém reiterar que essa análise de caráter teológico é apenas iniciada. Seu desenrolar e ápice estão reservados aos próximos volumes.

O desafio que ora se apresenta ao autor é, sobretudo, de cunho metodológico. De fato, Rubens caminha na esteira da metodologia adotada pelos teólogos latino-americanos da libertação, que partem da análise de uma realidade singular, assumindo o caráter contextual da reflexão propriamente teológica. No entanto, enfrenta os problemas que emergem da adoção de tal metodologia, a saber, como realizar a travessia de um estudo 
sócio-histórico do fenômeno religioso a uma reflexão propriamente teológica sobre os fundamentos da fé, sem engendrar um salto epistemológico? Como estabelecer critérios objetivos para submeter a fé à crítica? Como evitar o risco de manipulação dos dados sóciohistóricos em vista da perspectiva teológica? Uma vez que a experiência da fé cristã não é mais um objeto exclusivo da teologia, é possível transformar em questões teológicas os dados auferidos das análises sociológicas, sem que isto signifique uma subversão dos mesmos? Eis os limites a que o autor se propõe transpor. Para tal, empreende uma interpretação sociológica das três novas expressões da fé cristã a partir da abordagem tipológica de Ernest Troeltsch, que identifica três "corpos religiosos" do cristianismo em sua relação com o mundo: a Igreja, a seita e o espiritualismo místico. Convém mencionar que essa tipologia dos "corpos religiosos" ou esses tipos de socialização do cristianismo fincam suas raízes na obra do sociólogo Marx Weber. Rubens identifica possíveis analogias das novas "formas do crer" ou novas figuras do crer cristão por ele analisadas com esses tipos de socialização do cristianismo. Sublinha que cada figura privilegia um dos três tipos, de modo teórico ou prático, consciente ou não, ao mesmo tempo em que cada uma delas mantém relações com os três tipos de socialização.

Por fim, o autor traça alguns aspectos essenciais à elaboração da análise teológica a ser empreendida, como a norma da fé (regula fidei), um discernimento do crer, bem como a autocrítica dos preconceitos e a abertura na busca de novos paradigmas. Oxalá que os próximos volumes em edição portuguesa nos conduzam, como promete o autor, a um verdadeiro discernimento da fé cristã em contextos religiosos ambíguos! 